DOI: 10.2478/rjes-2014-0004

\title{
DERIVATIONAL VERSUS PHRASAL ADVERBIALS OF MANNER
}

\author{
DARIA PROTOPOPESCU \\ University of Bucharest
}

\begin{abstract}
This paper compares the usage of derivational and phrasal adverbial expressions of manner in English and Romanian. It also points to possible translational and learning problems due to selection peculiarities in the two languages. Both English as well as some of the Romance languages (among others French, Italian, Spanish), use both simple adverbs of manner (e.g. well) and derivational adverbs formed by adding a suffix to an adjective (e.g. poorly vs-mente adverbs in Romance).

Keywords: manner adverbs, phrasal adverbials of manner, derivational adverbials of manner
\end{abstract}

\section{Introduction}

Huddleston and Pullum (2002:612) assume adverbs to be elements that modify verbs among other parts of speech, and as such they are part of the adjunct category. Prepositions occurring as heads of PPs may also be considered to be part of the same category. In fact, almost every semantic type of adjunct can be realized by a phrase with either an adverb or a preposition as its head. Our paper discusses the instances of (derivational) manner adverbs and PPs functioning as adverbials of manner as in (1):
a. She did it carefully.
(derivational manner adverb)
b. She did it with great care.
(adverbial of manner PP)

Languages derive their adverbs in different ways allowing for a classification as proposed in Swan $(1988,1997)$ and Protopopescu (2012: 77). This classification triggers a clear split within the Romance family, where French, Italian and Spanish pattern along the lines of English as adverbial languages, with rich and productive adverbial suffixes, while Romanian has evolved more towards a partly adverbial language, similar in a way to German which uses the same form for both adjective and adverb. All languages mentioned allow for adverbial expressions of manner consisting of a preposition plus a noun phrase (e.g. with pleasure), but Romanian shows a propensity towards using the PP rather than the adverb variant.

Table 1

\begin{tabular}{|l|l|l|}
\hline $\begin{array}{c}\text { Adverbial languages: } \\
\text { English, French, Italian, } \\
\text { Spanish }\end{array}$ & $\begin{array}{c}\text { Non-adverbial } \\
\text { languages: German }\end{array}$ & $\begin{array}{c}\text { Partly adverbial languages: } \\
\text { Romanian }\end{array}$ \\
\hline $\begin{array}{l}\text { a. Present and past } \\
\text { participles are used as } \\
\text { verbal forms as well as } \\
\text { having adjectival uses. } \\
\text { Suffixation normal for }\end{array}$ & $\begin{array}{l}\text { a. Present and past } \\
\text { and adverbial functions. }\end{array}$ & $\begin{array}{l}\text { a. Past participles have } \\
\text { adjectival and adverbial } \\
\text { functions. }\end{array}$ \\
\hline
\end{tabular}




\begin{tabular}{|l|l|l|}
\hline adverbial uses. & & \multicolumn{1}{|c|}{} \\
\hline $\begin{array}{l}\text { b. There are few zero } \\
\text { forms; adverbs and } \\
\text { adjectives are normally } \\
\text { strictly distinguished. }\end{array}$ & $\begin{array}{l}\text { b. There are numerous } \\
\text { adjective-adverbs i.e. } \\
\text { zero forms which may be } \\
\text { used both as adjectives } \\
\text { and adverbs }\end{array}$ & $\begin{array}{l}\text { b. i. There are numerous } \\
\text { adjective-adverbs. } \\
\text { ii. The masculine singular } \\
\text { form of the adjective is used } \\
\text { as an adverb. }\end{array}$ \\
\hline $\begin{array}{l}\text { c. There is one dominant } \\
\text { adverb suffix. }\end{array}$ & $\begin{array}{l}\text { c. There is no dominant } \\
\text { adverb suffix. }\end{array}$ & $\begin{array}{l}\text { c. There are several adverb } \\
\text { suffixes: -(ic)esste, -mente, -iş } \\
\text { (iss)), but they are less } \\
\text { productive in the language. }\end{array}$ \\
\hline
\end{tabular}

However, if morphological rules for manner adverb formation are more or less available in all languages, the rules for selecting either derivational or phrasal adverbials of manner are hard to come by to say the least. There are most certainly language-specific constraints, and although there may be a large degree of one-to-one correspondence, the translation of a construction with an adverbial of manner into another language by using the same adverbial type can often lead to either ungrammatical $(2 b)$ or unnatural results (3a).
a. John waited calmly.
b. *Juan esperó calmamente.
a. ?John waited with calm.
b. Juan esperó con calma.

Therefore, one may be entitled to expect differences as far as either interpretation or grammaticality in what concerns the placement of derivational versus phrasal adverbials in English versus Romance languages. In what follows, we endeavour to discuss these differences and offer a pertinent analysis of the data.

\section{Contexts of Occurrence for Derivational and Phrasal Adverbials of Manner}

In order to better understand why we need to draw a line between derivational and phrasal adverbials, we need to take a closer look at their context of occurrence and the situations resulting thereof.

There are cases in which both the manner adverb and the [+ manner] PP seem to occur freely, the meaning remaining constant and both being grammatical as in (4) and (5), below.

a. John drives carefully.

b. John drives with care.

a. John acted justly.

b. John acted with justice.

In other contexts, however, there are possible significant meaning differences between the two, as in the set of examples under (6)-(8).

(6) a. John confessed his sins openly.

b. John confessed his sins with openness.

(7) a. John told the truth freely.

b. John told the truth with freedom. 
If John confessed his sins openly, he might have confessed them to anyone who would listen, but if he confessed them with openness, he may have been alone with his priest. Similarly, if John told the truth freely, he did so willingly and without hesitation, but if he told the truth with freedom, there was no danger or reprisal. Finally, if John told the story a second time forgetfully, he may have told the story again without a flaw or hesitation but failed to recall that he had already entertained his listeners. If John told the story a second time with forgetfulness, it may have been to a second audience and he forgot essential parts.

Looking further into the matter, we notice that there are contexts where both derivational and phrasal types are possible, but one seems to be preferred:

(9) a. John treated the matter laughingly.

b. John treated the matter with laughter.

(10) a. John performs ably.

b. John performs with ability.

In (9) and (10) the examples with the derivational adverb appear to be preferred by native speakers, whereas in (11) and (12) below, the examples with the phrasal adverbials are preferred ones.

(11) a. John looked at me questioningly.

b. John looked at me with question.

(12) a. John behaved reasonably.

b. John behaved with reason.

In English, the phrasal adverbial may not precede the verb. Therefore, examples such as (13) are ruled out, unless they occur parenthetically as in (14).

(13) a. * John with desire looked at the girl.

b. *John with perfection played the piano.

(14) a. John, with desire, looked at the girl.

b. John, with perfection, played the piano.

Similarly, no phrasal adverbial may intervene in the sequence transitive verb-direct object. This, however, has to do with the Adjacency Constraint, a parameter of the English language that with a few exceptions does not allow for any material to intervene and break this sequence.

*John played with perfection the piano.

It is important to mention the existence of this parameter for English, since Romanian does allow for adverbials to intervene between the transitive verb and its direct object, as will be shown in the following section.

To sum up, so far we can make the following generalization, mapping syntactic positions to semantic interpretations:

Table 2

\begin{tabular}{|c|c|c|}
\hline Syntactic Position & $\begin{array}{c}\text { Derivational Manner } \\
\text { Adverbs }\end{array}$ & $\begin{array}{c}\text { Phrasal Manner } \\
\text { Adverbials }\end{array}$ \\
\hline VP-external (Clausal reading) & Derived reading & Derived reading \\
& YES & NO \\
\hline
\end{tabular}




\begin{tabular}{|c|c|c|c|c|c|}
\hline \multicolumn{2}{|c|}{} & & & \\
\cline { 1 - 2 } VP-internal (VP reading) & Primary & Primary / & Primary & Primary / \\
Final & $\begin{array}{c}\text { Verb-ADV- } \\
\text { position }\end{array}$ & $\begin{array}{c}\text { DO (for } \\
\text { transitive } \\
\text { verbs) }\end{array}$ & $\begin{array}{c}\text { Yerived } \\
\text { YES }\end{array}$ & $\begin{array}{c}\text { Deading } \\
\text { reading NO }\end{array}$ & $\begin{array}{c}\text { YES } \\
\text { reading } \\
\text { NO }\end{array}$ \\
\hline
\end{tabular}

\section{The View from Romanian}

In what follows, we attempt a similar view for Romanian derivational adverbs and phrasal adverbials. As seen in Table 1 in section 1, Romanian makes extensive use of zero derivation as far as adverb formation is concerned, more often than not the masculine singular form of the adjective is also the form used for the adverb. Although this obviously lends itself to a lot of ambiguity, this is not the subject of this paper. The focus here is on the use of the derivational adverbs which mostly overlap adjectival forms.

(16) Maria mi-a vorbit ferm.

Maria spoke to me determinedly.

(17) Razele soarelui băteau delicat în geam.

The rays of the sun pounded delicately in the window.

(18) Studenții răspundeau inteligent.

The students were answering intelligently.

(19) Câinii mârâiau amenințător.

The dogs were growling menacingly.

(20) a. Ion aude clar vocea Mariei.

Ion hears Maria's voice clearly.

but $\quad$ b. Ion aude (clar) vocea nedistinctă a Mariei.

Ion hears clearly Mary's indistinct voice.

(21) Crainicul TV pronunță greşit numele străine.

The TV anchor pronounces foreign names mistakenly.

(examples from Mârzea 2010)

The same wrong predictions could be made, as in (Mârzea 2010), where the reading of the manner adverb in (22) is related to the verb, the subject and the direct object. Thus, the director may be violent in formulating his demand, the demand itself may be violent or the manner in which the demand is formulated is violent.

Directorul formulează violent cererea.

The manager formulates the request violently.

(examples from Mârzea 2012)

Here we explore the diagnostics available in order to properly interpret the manner adverbs discussed in the previous section. The expectation that the different classes in Ernst (2002) correspond to different interpretations is borne out by the fact that we can distinguish them by means of the different paraphrases available to them as indicated below.

(16') Maria mi-a vorbit ferm/în mod ferm/cu fermitate.

Maria spoke to me determinedly / in a determined manner / with firmness.

(17') Razele soarelui băteau delicat/în mod delicat/cu delicatețe în geam.

The rays of the sun pounded delicately/in a delicate manner /with delicacy in the window.

(18') Studenții răspundeau inteligent/în mod inteligent/cu inteligență.

The students were answering intelligently/in an intelligent manner.

(19') Câinii mârâiau amenințător/în chip amenințător ${ }^{*}$ cu amenințare.

The dogs were growling menacingly/in a menacing way $/ *$ with a menace.

$\left(20^{\prime}\right) \quad$ Ion aude clar/în mod clar/cu claritate vocea Mariei. 
(21') Crainicul TV pronunță greşit/în mod greșit/cu greșeli numele străine.

The TV anchor pronounces foreign names wrongly/in a wrong way / with mistakes.

(22') Directorul formulează violent/în mod violent/cu violență cererea.

The manager formulates the request violently/in a violent manner / with violence.

Certain manner adverbs whose interpretation is linked to the direct object cannot be paraphrased with $\hat{\imath}$ mod as the ones above, but they do allow for other adverbial PPs.

(23) Ana vinde ieftin/*in mod ieftin/cu bani puțini apartamentul.

Ana sells the apartment cheaply / *in a cheap manner / with little money.

Manner adverbs referring to the result of a process cannot be paraphrased by $\hat{\imath}$ mod:

(24) Mama frământă aluatul tare/*in mod tare.

Mother kneads the dough hard / *in a hard manner.

(25) Ion închide borcanele strâns/*in mod strâns.

Ion closes the jars tightly / *in a tight manner.

(26) Minerul dormea adânc/*in mod adânc.

The miner was sleeping sound $/ *_{\text {in }}$ a sound manner.

They do allow other adverbial PPs which, however, trigger a change in meaning from resultative to manner:

(24') Mama frământă aluatul tare / cu tărie.

Mother kneads the dough hard / with firmness.

(25') Ion închide borcanele strâns / cu fermitate.

Ion closes the jars tightly / with firmness.

(26') Minerul dormea adânc / în adâncime.

The miner was sleeping sound / in depth (in the underground).

In (24'), the PP adverbial cu tărie does not have the same resultative meaning as the derivational adverb tare, that is, the result of kneading the dough is not hard dough, but rather the manner in which the dough was kneaded was with firmness.

Table 3

\begin{tabular}{|c|c|c|c|c|c|}
\hline \multicolumn{2}{|c|}{ Syntactic Position } & \multicolumn{2}{|c|}{$\begin{array}{c}\text { Derivational Manner } \\
\text { Adverbs }\end{array}$} & \multicolumn{2}{|c|}{$\begin{array}{l}\text { Phrasal Manner } \\
\text { Adverbials }\end{array}$} \\
\hline \multicolumn{2}{|c|}{ VP-external (Clausal reading) } & \multicolumn{2}{|c|}{$\begin{array}{c}\text { Derived reading } \\
\text { YES }\end{array}$} & \multicolumn{2}{|c|}{$\begin{array}{c}\text { Derived reading } \\
\text { NO }\end{array}$} \\
\hline \multicolumn{2}{|c|}{ VP-internal (VP reading) } & & & & \\
\hline Final position & $\begin{array}{l}\text { Verb-ADV- } \\
\text { DO (for } \\
\text { transitive } \\
\text { verbs) }\end{array}$ & $\begin{array}{c}\text { Primary } \\
\text { reading } \\
\text { YES }\end{array}$ & $\begin{array}{l}\text { Primary / } \\
\text { Derived } \\
\text { reading NO }\end{array}$ & $\begin{array}{c}\text { Primary } \\
\text { reading } \\
\text { YES }\end{array}$ & $\begin{array}{c}\text { Primary / } \\
\text { Derived } \\
\text { reading } \\
\text { YES }\end{array}$ \\
\hline
\end{tabular}

\section{A Further Refinement}

While phrasal manner adverbials are clearly restricted to final position with VPinternal/ manner reading due to heaviness and prosody, but also interpretation, derivational manner adverbs seem to behave distinctly allowing both VP-external and VP-internal readings at times. In order to disambiguate this apparent lack of consistency/homogeneity within the class of derivational manner adverbs, we propose the following further refinement of mapping their syntactic positions to their semantic interpretations along the lines of 
(Schäfer 2002, Ernst 2002, 2004, 2006 and Protopopescu 2012), by proposing a split within the larger class of derivational manner adverbs. Thus, there are at least two subtypes: quality adverbs, whose primary reading is the clausal/VP-external interpretation, while the VP internal/manner interpretation is derived, and pure manner adverbs whose primary reading is generated in the lower position, adjacent to the VP, which triggers the manner interpretation, with the option of occurring higher in the clause VP-externally, where their interpretation changes to a clausal one.

Table 4

\begin{tabular}{|c|c|c|c|}
\hline \multirow[t]{2}{*}{ Syntactic Position } & \multicolumn{2}{|c|}{ Derivational Manner Adverbs } & \multirow{2}{*}{$\begin{array}{c}\text { Phrasal Manner } \\
\text { Adverbials }\end{array}$} \\
\hline & Quality Adverbs & $\begin{array}{c}\text { Pure Manner } \\
\text { Adverbs }\end{array}$ & \\
\hline $\begin{array}{l}\text { VP-external (Clausal } \\
\text { reading) }\end{array}$ & $\begin{array}{c}\text { Primary reading } \\
\text { YES }\end{array}$ & $\begin{array}{c}\text { Derived reading } \\
\text { YES }\end{array}$ & $\begin{array}{l}\text { Derived reading } \\
\text { NO }\end{array}$ \\
\hline $\begin{array}{l}\text { VP-internal } \\
\text { reading)* }\end{array}$ & $\begin{array}{c}\text { Derived reading } \\
\text { YES }\end{array}$ & $\begin{array}{c}\text { Primary reading } \\
\text { YES } \\
\end{array}$ & $\begin{array}{c}\text { Primary reading } \\
\text { YES }\end{array}$ \\
\hline
\end{tabular}

* Given the Adjacency Constraint for English, the preferred position of the adverb/adverbial in case of transitive verbs is the final position.

\section{Conclusions}

The comparison between the two classes that perform the same function yielded some unexpected results to the extent that the class of phrasal adverbials of manner is restricted to occur in the lower part of the clause, be it sentence final position in English or following the verb or sentence final position in Romanian. Derived manner adverbs, on the other hand, may also occur higher in the clause, which triggers a change in interpretation. In this case, derived manner adverbs acquire a clausal interpretation (the subject-oriented reading more often than not), i.e. a derived interpretation, something that is not available for phrasal adverbials of manner which are restricted to their VP-internal/manner interpretation, and thus to the lower syntactic position.

This is an additional argument in favour of those theories that regard the study of syntactic positions of adverbs in close relation to their semantic interpretations.

\section{Acknowledgements}

This work was supported by a grant of the Romanian National Authority for Scientific Research, CNDI - UEFISCDI, project number PN-II-IN-CI-2012-1-0366.

\section{References}

Ernst, Thomas. 2002. The Syntax of Adjuncts. Cambridge: Cambridge University Press.

Ernst, Thomas. 2004. "Principles of Adverbial Distribution in the Lower Clause." Lingua 114(6):755-777.

Ernst, Thomas. 2006. "On the role of semantics in a theory of adverb syntax." Lingua 117(6):1008-1033.

Huddleston, Robert and Pullum, Geoffrey K. 2002. The Cambridge Grammar of the English Language, Cambridge: Cambridge University Press.

Laenzlinger, Christopher. 1998. Comparative Studies in Word Order Variation: Adverbs, Pronouns and Clause Structure in Romance and Germanic. Amsterdam and Philadelphia: John Benjamins.

Mârzea, Carmen. 2010. Eterogenitatea adverbului românesc. Doctoral dissertation, Universitatea din București.

Protopopescu, Daria. 2012. The Syntax of Manner Adverbs in English and Romanian. București: Editura Universității din București

Schäfer, Martin. 2002. "Pure Manner Adverbs, Revisited," in Sinn \& Bedeutung VI, Proceedings of the Sixth Annual Meeting of the Gesellschaft für Semantik. Graham Katz, Sabine Reinhard, and Philip Reuter (Eds.). Osnabrück: University of Osnabrück, pp. 311-323. 
Swan, Toril. 1988. Sentence Adverbials in English: A Synchronic and Diachronic Investigation. Oslo: Novus. Swan, Toril. 1997. "From Manner to Subject Modification: Adverbialization in English." Nordic Journal of Linguistics 20(2):179-195.

\section{Notes on the author}

Daria Protopopescu is a lecturer with the English Department of the University of Bucharest. She teaches courses in the history of the English language, English terminology and English syntax. Her main research interests range from terminology to generative linguistics. In 2011 she defended her $\mathrm{PhD}$ thesis, on the syntax and interpretation of manner adverbs, a comparative study of English and Romanian. 